\title{
Julia Donaldson Türkçedeyken
}

\section{Ayza VARDAR OKUR'}

Çocuk yazını çevirisi araştırmalarının çoğu, ya çevirinin müdahaleci yönünün izlerini sürmekte ya da çeviriyi yerlileştirme-yabancılaştırma stratejileri ekseninde değerlendirmektedir. Çocukların hedeflendiği ancak büyükler tarafindan yazılan ve yönlendirilen bu alt-türde, kültürler arasındaki pedagojik yaklaşım farkları ve çocuk eğitimi bağlamındaki farklılıklar çevirmenlerin çeviri süreci kararlarını da etkilemektedir. Bunu göz önünde bulundurursak, çevirmenin bir ideolojiyi önceleme niyetinde olmadığı zamanlarda bile kaynak ve erek metinler arasında işlevsel farklılıklar ortaya çıkabileceği sonucuna ulaşırız. Bu çalışma, Julia Donaldson'ın “The Paper Dolls” adlı resimli çocuk kitabıyla Sevgi Atlıhan tarafından yapılan çevirisini işlevler bakımından karşlaştırmaktadır. Öncelikle çocuk yazınının işlevleri ve çeviri çocuk yazını eleştirisine güncel yaklaşımlar araştırılmış, bu doğrultuda kaynak metin biçem ve işlev odakları bakımından incelenmiştir. Sonrasında erek metinden örneklerle işlevin nasıl dönüştüğü ve bu farkların nelerden kaynaklanmış olabileceği değerlendirilmiştir. Julia Donaldson'ın duygusal gelişimi destekleyici, eğlendirici, hayal gücünü besleyici işlevleri erek metinde eğitici, öğretici, bilgilendirici işlevlere dönüşmüş ve kaynak metin yazınsal karmaşıklı̆ı̆ından arındırılmıştır.

Anahtar kelimeler: Çeviri eleştirisi, çocuk yazını, işlevsel yaklaşım, pedagojik çeviri.

\section{When Julia Donaldson Was in Turkish}

Translation of children's literature has been a popular topic among scholars in Turkey. Still, most of the studies focus on either manipulation through translation or domesticating-foreignizing strategies. In this sub-genre, which targets children but is mediated by adults, pedagogical differences and approaches to child education may affect translator's choices. Bearing this in mind, it may be foreseen that even when the translator does not prioritize an ideology, s/he may end up with functional differences between the source and target texts. The examples for the study are from Julia Donaldson, a British writer who has been translated into over 40 languages, and the translation of her "Paper Dolls" by Sevgi Atlıhan. The paper overviews the functions in children's literature and researches the recent studies in criticism of translated children's literature; and secondly analyzes the source text in terms of style and functions. Then, it compares the target and source texts to underline how the functions of the target text differ. The source text functions to trigger emotional development, add creativity and entertain the reader whereas the target text focuses on educational and informative functions. Also, the style and literary complexity of the target text is simplified. In the conclusion, the paper discusses why those changes may have taken place and what sort of outcomes they may have, or have had.

Key words: Translation criticism, children's literature, functional approach, pedagogical translation.

\section{1. Çocuk yazınının tanımı, genel nitelikleri ve işlevleri}

Çocuk yazınının, 2-14 yaş arasındaki bireyleri hedef alan; onların duygusal, bilişsel ve sosyal gelişimine katkı sunmaya çalışan kitaplardan oluştuğu kabul ediliyor. Bu tanım yeterli görünse de bir bilgiyi

Dr. Öğr. Üye. Kırklareli Üniversitesi, Fen Edebiyat Fakültesi, Mütercim-Tercümanlık Bölümü, ayzavardar@gmail.com [Makale kayıt tarihi: 26.6.2018-kabul tarihi: 15.8.2018] 
atlamakta. Çocuk yazınının öznesi ve son tüketicisi çocuklar olarak konumlandırılmış ancak üreticisi ve alıcısı yetişkinler. Hatta kitapları çevirenler, çevirileri inceleyenler de yetişkinler. 'Çocuklara hitap ediyor olmak' bütün bu özneler için ortak amaç; ancak bunun nasıl yapılacağı konusunda bir fikir birliği bulunmamakta. Fikir birliği bulunması gerekir mi, sorusu ayrı bir tartışmanın konusu ancak bu bildiride bir yazar ve çevirmenin 'çocuklara hitap etme' yöntemlerindeki farkların, kaynak metnin işlevini nasıl dönüştürdüğünden söz edilecektir. Bu doğrultuda kaynak metinde öne çıkan işlevler araştırllacak, erek metinde yaratılan işlevlerle karşılaştırılacaktır.

Çocuk yazını dediğimizde, yetişkin edebiyatıyla benzerliklerinin yanında, kendine özgü özellikler içeren bir alandan söz ediyoruz demektir. Yazarı, çizeri, editörü, yayıncısı yetişkin olan bir alandır bu. Aynı durum, çeviri çocuk edebiyatı için de geçerlidir. Bu kitapların çevirmeni, editörü ve yayıncısı yetişkindir. Bir kitabın alınmaya, okunmaya değer olup olmadığına karar veren de yetişkindir. Metnin çocuğa göreliğini, yararlarını ve zararlarını belirleyen, ona sansür uygulayan ya da metne müdahale eden kişiler, yazarıyla, çizeriyle, yayıncısıyla, eğitimcisiyle, kütüphanecisiyle, eleştirmeniyle yetişkindir (Neydim, 2006).

Bu çalışmada bir kitabı ve aynı kitabın çevirisi incelenecek olan Julia Donaldson, 'okul öncesi' sınıflandırmasıyla raflarda bulabileceğiniz resimli çocuk kitapları yazmaktadır. Okul öncesi çocuk kitaplarının okunma süreci de bir yetişkin (ya da kitabı sesli okuyan herhangi biri) eşliğinde gerçekleşmektedir. Dolayısıyla yetişkin, kitabın alınmasına, okunmasına (satıp satmayacağına) karar verdiği gibi; okuma sürecinde de belirleyici olabilmektedir. Bütün bu süreçlerde söz sahibi yetişkinin, yayınevini ve dolayısıyla çevirmen stratejilerini de etkileyeceğini söyleyebiliriz.

Okul öncesi çocuk yazınında görseller kitabın yazılı metni kadar önem taşır. Yazılı metin kadar çizimlerde olup biten de okuma sürecine dahildir. Bu iki anlatım yöntemi ve dili, okuma sürecinde eşleştirilmeye çalışılır. "Çizimler, metnin şekli ve sunduğu fiziksel ortam yalnızca süsleme amacı taşımaz, resimli kitabın ikili bütüncesinin bir tarafıdır ve kitabın içeriğini, içeriğinin farklı okurlar tarafından nasıl algılanacağını etkiler" (Oittinen, 2000). Hatta kimi zaman görsellerle yazılı metin arasında bir tutarsızlık olduğunda okur (ya da dinleyici) bunu fark eder. Görseller hakkında konuşarak okur ve dinleyici kitabın sınırlarını genişletir, eğlenceli zaman geçirmenin farklı yollarını üretirler.

Resimli çocuk kitaplarının çoğunda ses benzerlikleri ve uyaklar, hatta kimi zaman hece ölçüsü bulunmaktadır. Bu durum bebeklikte oluşan ve ninnilerle desteklenebilen ritim-ses gibi unsurları kitaplara aktararak dil gelişimini sürdürür, çocuklara kitap okuma alışkanlı̆̆ı kazandırma amacını pedagojik bir şekilde destekler. Sesli okunmak üzere de yazılıyor olmaları, bu türü diğer yazınsal türlerden açıkça ayırmaktadır. Öyle ki Riitta Oittinen (2000) çocuk yazınını "çocuklar tarafından sessiz ve çocuklara sesli okunan yazın" olarak tanımlamıştır. Bu metinlerin sesli okunuyor olması çevirmenlerin çeviri sürecinde de göz önünde bulundurmaları gereken bir durumdur. Metnin ses, ritim, uyak, hece gibi niteliklerinin gözetilmesi ve cümlelerin sesli okunabilecek uzunlukta yapılandırılması gibi etkenlerde çevirmen kararları büyük önem taşır.

Çocuklar için yazılan kitaplardaki dilin nasıl olması gerektiği konusunda bir uzlaşma bulunmamaktadır. Geleneksel tutumlar sözcüklerin basit ve gündelik, cümlelerin sade ve kısa olması gerektiğini savunurken 1970'lerden sonra yazın, çocuk gelişimi ve çocuk yazınıyla ilgilenenler bunun gerçekçi olmadığını ortaya koymuşlardır. İçerik konusunda da tartışmalar benzer şekilde ilerlemiştir. Çocuğun travma yaşayabileceği birçok olgu kitaplarda işlendiğinde daha kabul edilebilir hale gelebilir. Günümüzde anne-baba boşanması ya da ölüm gibi konular çocuk kitaplarında işlenebilmektedir. 
Sonuçta bu içeriklerin hangilerinin okul öncesi çağdaki çocuğa okunacağı; kullanılan dilsel öğelerin hangilerinin çocuğa yansıtılacağı da son tüketici olarak ebeveynlerin karar vereceği durumlardır.

Resimli çocuk kitaplarının çocuk gelişiminde belli işlevleri bulunmaktadır. Bunlardan ilki eğitici/öğretici/bilgilendirici işlevdir. Kitaplarla çocuğun sözcük dağarcığını geliştirebilir, ona yeni dil kalıpları ve deyişler öğretebiliriz. Özellikle çeviri kitaplardan söz edecek olursak çocukların farklı kültürlere ilişkin birçok bilgi bulabileceğini söyleyebiliriz. Evrensel değerlerin, toplum ve aile değerlerinin eğitimi kitaplar yoluyla mümkündür. Yaşamın temelleri, sosyal normlar, toplumsal cinsiyete yönelik roller, tabular, başkaldırılar, korkular ve başka bilinmedik birçok somut-soyut kavram kitaplar yoluyla verilebilir çocuklara.

İkinci olarak, kitaplar çocukların yaratıcılığının, hayal dünyasının ve hayal kurma becerilerinin gelişmesinde rol oynayabilir. Kitaplarda gerçek ve gerçeküstü birlikte yer alarak çocuğun çatışmalarda bulabileceği çözüm yollarını genişletebilir, soyut zekasına katkı sağlayabilir. Belki de böylece günümüz insanının geliştirmeye çalıştığı yaratıcı, sorun-çözücü insan niteliği de desteklenir. Ayrıca okuma sürecinde kitaplardaki içerik üzerine yapılan konuşmalarla çocuğun eleştirel yanı uyarılarak okur genç yaşta eleştirel düşünceyle tanıştırılabilir.

Çocuk yazınının çocuğun duygusal dünyası üzerinde de işlevi vardır. Karakterlerle empati kurmak, taraf tutmak/karşı durmak, çatışmalarda yaşanan duyguların betimlenmesi çocuğu duygusal yönden uyarır, etkiler, ona kendi duygularını ifade etmede yeni yöntemler sunar. Bu işlevler okuma sürecinin nasıl yürütüldüğüyle çok ilgilidir. Sosyalleşmeyi de bu sürecin uzantısı olan bir işlev olarak görebiliriz. Çocuk sosyal ortamda karşılaşabileceği sorunları ve bunların çözüm yollarını kitaplarda önceden gözleyebilir. (Bu son iki işlevi eğitim-öğretim işlevine dahil etmek de mümkün ancak özellikle resimli kitaplarda bu son ikisi, kitabı okuyan kişinin yönlendirmesine bağlı olduğu için ayrıca ifade etmekte fayda var). Dahası, kitabı okuyan kişiyle geçirilen zaman bile bir tür sosyalleşmedir.

Çocuk kitaplarının eğlendirici işlevi, aslında en önemli işlevdir. Bu iddiadaki ilk savunma, kitabın eğlenceli olmazsa okunmayacağıdır. Okunmayan bir kitapta diğer işlevlerin hiçbirine ulaşılamaz. İkinci savunma ise çocuklara kitap okuma ediminin kitap okuma alışkanlığı kazandırma amacıyla ilintili olmasıdır. Kitapla yaşanan deneyimin eğlenceli oluşu, bu deneyimi tekrarlama isteğini körükleyecektir. Dahası çocuk gelişimi alanının önemli bulgularından biri çocukların mutlu ve neşeli olduğunda çok daha iyi öğrendiği, davrandığı ve düşündüğ̈̈dür ki bu çocuk kitaplarının diğer bütün işlevlerini destekler.

Sonuç olarak çocuk yazınının işlevleri eğitmek-öğretmek-bilgilendirmek, duygusal gelişime katkı sunmak, sosyalleştirmek, yaratıcılık aşılamak ve eğlendirmek olarak özetlenebilir. Bu işlevlerin hepsinin her kitapta bulunması beklenemez. Ancak bir kitabın bu işlevlerden hangisini/hangilerini bulundurduğu ya da hangi işlevinin ağırlıkta olduğu çevirmenlerin çeviri süreci öncesi saptamaları gereken konulardan biridir.

\section{2. Çocuk yazını çevirisine yaklaşımlar}

19. Yüzyıla kadar günümüz tanımıyla sözünü ettiğimiz çocuk yazını henüz çok yaygın değildir. Çocuklara anlatılanlar genellikle sözlü geleneğin bir ürünüdür. Halk öyküleri, ninniler, tekerlemeler, söylenceler, peri masalları bunlardan bazılarıdır. Aydınlanma Çağında çocuk yazınının gelişimi de ivme kazanır. Ancak bu dönemdeki akılcılık ilkesi, eğitime sert bir didaktizm ile yansımış, ahlaki değerler ve öğreticilik ön plana çıkmıştır. Gillian Lathey, ${ }^{1825}$ 'lerden başlayarak İngiltere'deki çeviri çocuk yazını kitaplarının 
önsözlerini incelediği "The Translator Revealed: Didacticism, Cultural Mediation and Visions of the Child Reader in Translator's Prefaces” ["Çevirmen Sahnede: Çevirmen Önsözlerinde Didaktiklik, Kültürel Arabuluculuk ve Çocuk Okur Tahayyülleri”] adlı makalesinde vurgunun öğreticilikte olduğunu ve bu uğurda çevirmenlerin genellikle erek normlar odaklı uyarlama stratejisini benimsediğini tespit etmiştir.

Telifli yazarların ve özgün anlatıların pedagojideki gelişmelere koşut olarak artmasıyla çocuk yazını, hem yazın dünyası araştırmacıları hem de çeviribilim araştırmacıları için önemli bir alan haline gelmiştir. 1900’lerin ortalarında, çocuk yazını çevirisine yaklaşımların çeviribilimdeki ilerlemelere paralellik sergilediğini görebiliriz. "Çeviriler nasıl olmalıdır?” sorusundan başlayıp "Çeviriler nasıldır?" sorusuna geçiş; durumun tespitinden sonra "Çeviriler neden böyledir?" gibi eleştirel soruların sorulmasıyla günümüz tablosu ortaya çıkmıştır. Dil ve dilbilim odaklı yaklaşımlarda kaynak metin ve erek metin arasında bir eşdeğerlik aranmaya çalışılmış, bunun dereceleri normatif ya da betimleyici çalışmalarda incelenmiştir. 1970'lerde kültür dönemeci ortaya çıkmış ve çeviribilim incelemelerinde ağırlıklı olarak erek odaklılık benimsenmeye başlanmıştır.

Çeviri eleştirisine eşdeğerlik kavramı üzerinden yaklaşan birçok kültürel dönemeç kuramcısının aksine, Hans J. Vermeer'in olgunlaştırdığı Skopos yaklaşımında herhangi bir çeviri sürecinde çevirinin yöntemini ve stratejisini belirleyecek olan, çevirinin amacıdır. Burada amaç sözcügü̈; işlev ya da niyet olarak da algılanabilir. Bu bakışla çevirmene bir yöntem dayatılmaz; ancak ondan verdiği kararlarda seçtiği işlev/amaç doğrultusunda tutarlı olması beklenir. Bu yaklaşımda içkin bir eşdeğerlik kavramı bulunmasa da çeviri karşılaştırılması erek ve kaynak metinlerin ayrı ayrı incelenmesinden sonra yapılır; yani kaynak metin kendi bütünlüğü içerisinde işlevleri bakımından; erek metin de kendi bütünlüğü içerisinde işlevleri bakımından incelenir ve karşlaştırma/ değerlendirme/ eşdeğerliğin incelenmesi bunlardan çlkacak sonuçlara göre yürütülür.

Betimleyici çeviribilim ekolünde ortaya atılan Çoğuldizge Kuramı çeviri çocuk yazını konusunda en çok başvurulan araştırmacılardan Zohar Shavit’i etkilemiştir. Ona göre çocuk yazını, yazın geleneğinde çevresel konumdadır ve bu yüzden çevirmen daha serbest kararlar alabilmektedir:

Yetişkinler için yazılan kitapların günümüzdeki çevirmenlerinin aksine, çocuk yazını çevirmenleri çok daha serbest kararlar vermektedirler. Bunun sebebi, çeviri çocuk yazınının çocuk yazını çoğuldizgesindeki çevresel konumudur. Çevirmen metni değiştirerek, genişleterek, kısaltarak, silerek ya da metne eklemeler yaparak kaynak metne müdahalelerde bulunmaktadır. (Shavit 1986, 112)

Bu 'çevresel' durum ülkemiz açısından geçerli midir (piyasada özgün eserden çok çeviri eser mi vardır?) sorusunun cevabı bu çalışmada araştırılmamış olsa da, Shavit’in saptadığı çevirmenlerin metne müdahale etme sebepleri yerel bağlamda geçerli olabilir. Shavit’in aynı makalesine göre müdahale koşulları şöyledir:

Toplumun (belli bir zamanda) eğitsel açıdan “çocuk için iyi” diye niteledikleri doğrultusunda metni çocuğa uygun ve yararlı hale getirmek için; olay örgüsü, karakterler ve dili var olan toplum algısına göre çocuğun okuyabileceği ve anlayabileceği hale getirmek için. (Shavit 1986, 112)

Shavit'in iki koşul için de toplumun algısını dikkate aldığı görülmektedir. İlkindeki endişeler uygunluk ve yararlılık bağlamındayken ikincisindekiler anlaşılmak-okunabilmek üzerinedir. İsveç çocuk yazını araştırmalarının kurucu babası olarak konuyla ilgili birçok çalışması bulunan Göte Klingberg'e göre uyarlama, didaktikleştirme ve arındırma; çocuk yazını çevirisinde çok öncelerden beri var olan stratejilerdir ve bunların birçok amacı ve türü bulunmaktadır. 
Erek odaklı çeviri eğiliminin sıkı takipçilerinden Riitta Oittinen ise çocuk yazını çevirmenleriyle yetişkin yazını çevirmenlerinin ortak sorununun görünmezlik olduğunu vurgular. Uyarlama stratejisinin ise çevirmeni görünür yaptığını; zaten çocuk yazınında çevirmenin hedef kitlesi olan 'çocuk'a sadık kalarak erek odaklı bir uyarlama stratejisi benimsemesi gerektiğini ifade eder (Oittinen 2000, 80-81). Radegundis Stolze, çocuk yazınının çevirisinde yetişkin yazınının çevirisinden farklı olarak kolaylaştırma, açıklama, sadeleştirme gibi uygulamaların sıklıkla başvurulduğundan söz eder. Pinokyo'nun çevirilerini inceleyip kimi şakaların bile açıklandığını tespit eden Stolze’ye göre, çocuklar anlamaz endişesiyle başvurulan bu "kolay okunan metin yaratma çabasının ödülü çoğunlukla sıkıcı bir erek metindir" (Stolze 2003, 209).

Jan Van Coillie, "Children's literature in translation: Challenges and Strategies" adlı derleme kitabında yayınladığı "Character Names in Translation: A Functional Approach" (2006) ["Çeviride Karakter Adları: İşlevsel Bir Yaklaşım”] başlıklı makalesinde çevirmen kararlarının metnin işlevini nasıl kaydırdığını kaynak metinlerdeki özel adların çevirileri üzerinden örnekler. Ona göre karakter adlarını yerlileştirmek çocuk yazının çevirisinde çokça başvurulan uygulamalardan biridir. Ancak bu işlem sonrasında kaynak metinlerdeki bilgilendirici, eğitici, duygusal gelişime yönelik, eğlendirici, yaratıcıllk geliştirici gibi işlevlerde odak kayması yaşanabilir. Örneğin kaynak metnin odağında duygusal gelişimi destekleyen ya da eğlendirici işlev öne çlkıyorken çevirmen kararlarıyla bu odak bilgilendirici işleve kayabilir.

Çocuk yazını çevirisine yönelik yaklaşımlarda uyarlama ve didaktik çeviri kavramları üzerinde çokça durulduğundan söz edebiliriz. Uyarlama ya da yerlileştirme doğrultusunda alınan kararların niyeti çoğunlukla erek kültür normlarına yakın bir metni çocuklara sunmaktır. Ancak bilgilendirici-eğitici işlevlerin odağa alındığı didaktik çeviride amaç nedir ve bu amacın sonuçları nelerdir? Bilgi verme yoğunluğu arttırılmış bir erek metinle acaba pedagojik olarak ne gibi sonuçlara ulaşlacaktır? Aşağıda Julia Donaldson'ın "The Paper Dolls” adlı kitabı ve çevirisi, işlevsel yaklaşıma göre incelenecek ve sonuçlar yorumlanacaktır.

\section{Julia Donaldson, “The Paper Dolls" ve "Kağıt Bebekler"}

\subsection{Julia Donaldson}

Julia Donaldson, 1948 Londra doğumlu, 1993’ten beri şiir, şarkı, oyun, öykü, resimli kitap türlerinde ürünlerle çocuk yazınına katkı sunmuş bir yazardır. Kimi kitapları animasyonlara ve sahneye aktarılmıştır. Kitaplarını internet sitesinde resimli kitaplar, genç okurlar, kurmaca, drama gibi başlıklara ve bunların altında çeşitli yaş gruplarına ayrılmış olarak bulmak mümkündür. Bu ayrımlara göre dili ve temaları değişse de Donaldson genellikle gerçeküstü karakterler yaratarak hayal dünyasına bolca başvurmaktadır. Anlatılarında hayvanlarla insanların, kimi zaman söylencesel hayali yaratıkların buluştuğu, kimi zaman klasik öykülere anıştırmalar taşıyan bir evren bulunur. Doğa, korkular, iletişim, açgözlülük, paylaşım, çirkinlik/güzellik gibi soyut temalar üzerine kurulu öykülerinde Donaldson'ın karakterleri başlarına gelen kötü durumlardan şanslarının, yeteneklerinin ya da zekalarının yardımıyla; genellikle kendi çabalarıyla kurtulurlar. Öykülerde ölüm ya da fiziksel savaş yoktur; büyümek, bir şey öğrenmek ya da hayal kurmak gibi konular hiç açıç̧a ifade edilmez. Aynı zamanda müzisyen olan Donaldson öykülerini uyaklı, çoğu zaman ölçülü yazar. Kısa tümceler ve karmaşık olmayan bir dille kurulu anlatılarında söz oyunlarına ve nükteye bolca yer verir. Kitaplarının çizimlerini Axel Sheffler, Rebecca Cobb, Anna Currey gibi sanatçllar yapmıştır. 
Julia Donaldson’ın resimli kitapları Türkçeye 1001 Çiçek Kitaplar ve Türkiye İş Bankası Kültür Yayınları tarafından çevrilmiştir. 1001 Çiçek Kitaplar Derin Erkan adlı çevirmenle çalışırken Türkiye İş Bankası Kültür Yayınları Sevgi Atlıhan, Ali Berktay, Nevin Avan Özdemir gibi farklı çevirmenlerle çalışmıştır. Bu çalışmada Sevgi Atlıhan’ın çevirdiği “Kağıt Bebekler” incelenmektedir.

\section{2. The Paper Dolls}

“The Paper Dolls”, Julia Donaldson'ın İngilizce yazdığı ve Rebecca Cobb tarafından görselleri oluşturulan bir resimli çocuk kitabıdır. Macmillan Children's Books Yayınevi tarafından İngiltere'de 2012 yılında yayınlanmıştır. Kitap, yaptığı kâğıt bebeklerle oynayan bir kız çocuğunu anlatır. Kâğıt bebekler ve kız kimi engeller ve zorluklarla karşılaşsa da onlarla mücadele etmeyi başarırlar. Kitabın genel olarak sunduğu düşünce, küçük bir çocuğun bir kâğıt parçasını oyuncak haline getirip hayal dünyasını ona eklediğinde çok eğlenebileceğidir. Kaynak metinde öne çıan iletilere göre, riskler alarak heyecan ve eğlence yaşanabilir, dayanışarak tehlikeler atlatılabilir ve bu sırada kayıplar da olsa güzel anlar belleğimizde sonsuza dek kalır. Örneğin kitaptaki kız, kitabın sonunda anlaşıldığı üzere büyükannesini kaybetmiştir ama onu belleğinde yaşatmaktadır. Bu noktada normal koşullarda bir çocuk için çok travmatik olabilecek ölüm kavramı, kızın oyun aracının kaybıyla eşleştirilmiş ve ölen insanın anısını yaşatma üzerinden doğallaştırılmıştır. Ana konuları dayanışma, dönüşüm, kayıp-kazanç ve üzüntü/korkularla baş etme yolları olan kitabın kaynak metni şöyledir:

There was once a girl who had tiger slippers

And a ceiling with stars on it/ And a butterfly hairslide which she kept losing

And two goldfish/ And a nice mother who helped her to make some paper dolls

They were Ticky and Tacky / and Jackie and Backie

and Jim with two noses / and Jo with the bow

And they danced / and they jumped / and they sang

And they met a dinasour/ who clawed and roared./ and said "I'm going to get you!"

But the paper dolls sang/ "You can't get us oh no no no!"

We're holding hands and we won't let go.

We're Ticky and Tacky and Jackie the Backie

And Jim with two noses and Jo with the bow!"

And they jumped onto a bus/ And rode to a farmyard and danced with the pigs

Then they lay on a rooftop and stared at the stars/ Till a tiger slang out of his den

And he crouched and snarled / And said, "I'll lep up and catch you!"

But the paper dolls sang/ "You can't catch us oh no no no!"

We're holding hands and we won't let go.

We're Ticky and Tacky and Jackie the Backie

And Jim with two noses and Jo with the bow!"

And they floated down the stairs/ And they danced round the honey pot

And kicked crumbs and explored an island

Till a fierce crocodile grinned his grin/ And gnashed his teeth

And said, "I'm coming to crunch you!"

But the paper dolls laughed and sang/ "You can't crunch us oh no no no!"

We're holding hands and we won't let go./ We're Ticky and Tacky and Jackie the Backie

Adress1

Kurklareli University, Faculty of Arts and Sciences, Department of Turkish Language and Literature, Kayalı Campus-Kırklareli/TURKEY e-mail: editor@rumelide.com 
And Jim with two noses and Jo with the bow!"

And they hopped/ Into the garden/ and they sniffed the flowers and chatted to a ladybird

And lay down in a forest of grass

But along came a boy/ With a pair of scissors/ And he said, "I'll SNIP you!"/ And he did

He snipped them into tiny little pieces/ And he said, "You're gone forever."

But the paper dolls sang/ "We're not gone. Oh no no no!"

We're holding hands and we won't let go.

We're Ticky and Tacky and Jackie the Backie

And Jim with two noses and Jo with the bow!"

And the pieces all joined together and the paper dolls flew

Into the little girl's memory/ Where they found white mice and fireworks

And a starfish soap/ And a kind granny/ And the butterfly hairslide

And more and more lovely things each day/ And each year

And the girl grew/ Into a mother/ Who helped her own litlle girl make some paper dolls

They were Poppy and Pinkie/ And Binkie the Blinkie/ And Fred with one eyebrow/ And Flo with the bow

And they jumped/ And they danced/ And they sang

\subsubsection{Kaynak Metnin İncelenmesi}

Kaynak metin, biçimsel açıdan bakıldığında ardışık sayfalarda devam eden uzun tümcelerden oluşur. Ses ve ritim ögeleri gözetilerek yazılmış bu anlatıda aliterasyona çok sık başvurulmuştur. İçerikte ise kız ve kâğıt bebeklerin eğlenceli oyunlarında karşılarına çıkan tehlikeler dayanışmayla atlatılmıştır. Yazarın karmaşık bir biçem kullandığı söylenebilir. Üst düzey sözcüklere ("fierce" - "haşin") ve eğretilemelere ("forest of grass" - "çimen ormanı") yer verilmiştir. Resimlerdeki bilgiler tekrarlanmamış, duygular doğrudan söylenmemiştir. Duygu betimlemeleri okurun (ve dinleyicinin) yorumuna bırakılmıştır. Böylece kaynak metnin duygusal gelişimi destekleyici işlevi belirginleştirilmiştir. Kitabı okuyan kişi ile dinleyen kişinin okuma sürecinde iletişim kurarak, mantık yürüterek, duygu tanımlamaları yaparak, eleştirel sorular eşliğinde gerçekleştireceği sohbet için yeterince olanak sunulmuştur. Bunu kaynak metnin sosyalleştirici işlevi olarak da yorumlayabiliriz.

Kaynak metnin odaktaki işlevi yaratıcılık geliştirici işlevdir. Kendi yaptığı kâğıt bebekleri ve yaşam alanındaki eşyaları kullanarak hayali bir oyun yaratır ana karakter. İkincil işlevin duygusal gelişimi destekleme işlevi olduğu söylenebilir. Kâğıt bebeklerin karşılaştıkları engeller büyük, korkunç, güçlüdür ancak karakterler dayanışmayla bunların üstesinden gelirler. Sonraki öne çıkan işlevin eğlendirici işlev olduğu söylenebilir çünkü karakterler oradan oraya zıplayıp dans ederek şarkı söylerler. Yukarıda bahsi geçen sosyalleştirici işlevin de eğlendirici işlev kadar önem taşıdığı söylenebilir. Kaynak metinde doğrudan eğitici/ bilgilendirici işlev taşıyan unsurlara rastlanmamaktadır.

\subsection{Kâğıtt Bebekler}

Türkiye İş Bankası Kültür Yayınlarından Sevgi Atlıhan'ın çevirisiyle çıkan "Kâğıt Bebekler"in tümcelerinin, sıkça kullanılan eylem bildiren yargılarla kısaltılmış olduğu gözlemlenmektedir ve bu durum metnin devamlılı̆̆ını sekteye uğratmaktadır. Ses benzerliği, yüklemdeki zaman ekleriyle kurulmuştur ki bu durum ses benzerliğinin çeşitliliğini kısıtlamaktadır. Kaynak metinde göze çarpan 
eğretileme çevrilmemiş, karmaşı sayılabilecek sıfatların yerine "büyük", "kocaman”, "eğlenceli” gibi basit sıfatlar tercih edilmiştir. Bütün bu seçimlerle erek metnin biçimsel olarak daha basit, biçemsel olarak daha az yazınsal olduğu söylenebilir. Kavramsal açıdan bakıldı̆̆ında ise duyguların doğrudan tanımlandığı, erek kültürdeki çocuk okurlara korkutucu gelebileceği varsayılan kimi unsurların elendiği, erek kültürde kabul görmeyen ya da dışlanan kimi unsurların aktarılmadığı gözlemlenir. Dolayısıyla kavramsal açıdan da bir sadeleştirme söz konusudur. Ancak erek metin yine de kaynak metinden daha uzundur. Bu da kimi eklemeler yapıldığını göstermektedir.

Erek metnin işlev odakları, önem ve yoğunluk sırasına göre değerlendirilecek olursa eğitici/ bilgilendirici işlevin ön planda tutulduğu görülmektedir. Duygusal gelişimi destekleyici ve sosyalleştirici işlevlere açıç̧a ket vurulmuştur. Yaratıcılığı teşvik edici işlev, kaynak metinde hem içerik hem de biçemle sağlanmıştır. İçerikle ilgili kısım konu/ bağlam aktarıldığı için korunmuşken biçemle ilgili kısım aktarılamamıştır. Kavramsal ve biçemsel sadeleşme, ses unsurlarının çevrilememesi, bunlara ek olarak kitabın uzamasıyla metnin eğlendirici işlevi de indirgenmiştir. Aşağıda bu işlev kaymasının hangi çeviri seçimleri üzerinden gerçekleştiği örneklendirilmektedir.

\section{4. İşlev Kaymasına Örnekler}

Kitabın girişinde, ana karakterin iki kırmızı balığı vardır ancak erek metne kızın bu iki balığı asla unutmadığı, her gün beslediği eklenmiştir. Ayrıca kaynak metindeki kızın ona kâğıt bebek yapımında yardımcı olan bir annesi varken erek metinde kızın en sevdiği şeylerden biri annesiyle birlikte kâğıttan bebekler yapmaktır. Hemen sonrasında, kâğıt bebek yapımıyla ilgili bilgi eklenmiştir: "Beyaz bir kâğıt parçası alır, çocuk makasıyla keserek bebek şekilleri çıkartırdı. Sonra da her biri başka bebek olacak şekilde onları boyardı.” Çevirmen erek kültürde kâğıt bebek yapımının çok yaygın bir uğraş olmadığı düşüncesiyle ek bilgi verme ihtiyacı hissetmiş olmalıdır. Yine erek metinde bir sıfat eklenerek bu kâğıt bebeklerin isimlerinin eğlenceli olduğu yönünde yönlendirme yapılmıştır: "Bebeklere eğlenceli adlar da vermiş̧ti”. Kaynak metinde kız bebeklerle dans edip hoplar zıplar, şarkı söyler ancak erek metinde kız "kâğıt bebekleriyle oynamayı çok seviyordu" denir. Yani hem duygu doğrudan tanımlanmıştır hem de kaynak metinde kâğıt bebekler oyunun etkin bir parçasıyken erek metinde ana karakterin oyuncağı olarak tanıtılmıştır. Böylece duygusal gelişim destekleyici, sosyalleştirici ve yaratıcılık güdüleyici işlevler indirgenmiştir.

Kaynak metinde karakterler oyunun akışında kimi tehlikelerle karşılaşırlar. İlk tehlike olan dinozor, kaynak metinde fiziksel olarak betimlenmemişken (zaten resimlerde neye benzediği görünmektedir) erek metinde bir ön bilgiyle bu tehlikenin olumsuz bir durum olduğu sezdirilir: "Sonunda olan oldu". Ayrıca dinozor büyük, mavi gibi görselleri açıllayıcı sözcüklerle betimlenir. Böylece duygusal gelişim destekleyici ve sosyalleştirici işlevler indirgenir. Kitap boyunca sıkça tekrarlanan nakarat kısmında kaynak metne göre kâğıt bebekler el ele tutuşup hiç birbirlerini bırakmazlar, şarkı söyleyip dans ederek tehlikeden kaçabilirler. Oysa erek metinde hiç korkmayan, cesur, akıllı gibi sıfatlar eklenmiştir kâğıt bebeklere:

\footnotetext{
“Ama kâğıt bebekler hiç korkmadılar/ Hep birlikte şarkı söyleyip dans ettiler/ Bizi yakalayamazsın! /Bizim gibi hoplayıp zıplayamazsın! /El ele tutuşuruz ve asla bırakmayız. /Hiçbir şeyden korkmayız! / Herkes bilir bizim ne kadar cesur olduğumuzu. /Şaşkın Taşkın, Hülya ile Fulya, iki burunlu Can ile fiyonklu Canan'ın çok akıllı olduğunu!"
}

Burada eğlendirici ve duygusal gelişimi destekleyici işlevler, çevirmen tarafından doğru olduğu düşünülen duygu ve tutumların doğrudan dayatılmasıyla eğitici işleve dönüştürülmüştür. Kitabın 
başlangıcındaki sorumluluk duygusu aşılama çabasına korkusuz, akıllı, cesur bir çocuk modeli çizme çabaları da eklenmiştir.

Sonrasında, karakterlerin bindiği otobüs kaynak metinde betimlenmemişken erek metinde "büyük" olarak betimlenmiştir. Bu otobüsle gidilen çiftlikte karakterlerin domuzlarla dans ettiği yazılmışken erek metinde bu hayvanın adı bulunmamaktadır. "Çiftlikte çok eğlendiler, çiftlik hayvanlarıyla oynayıp dans ettiler.” Deneyimin eğlenceli olduğu erek metinde doğrudan verilen sıfatla sabitlenmiştir. Çevirmen erek kültürel normlarda domuzun çok sevilmeyen bir hayvan olduğunu bilmektedir çünkü İslam inancina göre domuz eti yenmesi yasaktır. Burada, görselin izin verdiği ölçüde müdahalede bulunarak belki de metnin İslam inancına yakın yetişkinler tarafından dışlanmaması için çabalamıştır çevirmen. Büyük ve eğlenceli gibi sıfatların tekrarıyla duygu betimlemesi yapılmış, duygusal gelişim destekleyici işlev böylece azaltılmıştır.

Kaynak metinde karakterler bir çatıya çıkıp yıldızları seyrederler ancak erek metinde bu çatının "bebek evinin çatısı" olduğu bilgisi verilmiştir. Görsel olarak verilen metinde zaten bulunan bilgi tekrarlanmıştır. Belki de görselleri iyi takip etmeyen bir çocuğun gerçek bir evin çatısına çıkmayı aklına koyması çevirmen tarafından engellenmek istenmiştir. Aslında bu şekilde hayal gücü de kısıtlanmış, yaratıcı işleve ket vurulmuştur. Burada çevirmenin olası korumacı çocuk yetiştirme eğilimleri etkili olmuş da olabilir. Karakterlerin karşılaştı̆̆ kaplan yine kaynak metinde betimlenmemişken erek metinde "kocaman" olarak açıklanmıştır. Bu açıklamalarla yaratıcı ve duygusal gelişimi destekleyici işlevler arka plana itilmiştir.

Sonra, kaynak metinde kâğıt bebekler kız çocuğunun kahvaltı tabağındaki ekmek kırıntılarını tekmelemektedir ancak erek kültürde bu kabul görecek bir davranış olmadığından çevirmen kendi kültürel normlarıyla metne ikinci kez kültürel bir sansür uygulayarak ekmek kırıntılarını bebeklere tekmeletmez, inceletir. Karakterlerin bu olgun ve ölçülü davranışı metnin eğlendirici işlevini bir hayli geriye atmaktadır.

Karakterlerin karşlarına çıkan bir engel de kaynak metinde "korkunç" olan ama erek kültüre "yemyeşil" olarak taşınmış bir timsahtır. Çevirmen bu sözcüğün çocuğu duygusal açıdan olumsuz etkileyeceğini, gereceğini, onu gerçekten korkutacağını düşünmüş olabilir. Ancak kaynak metnin işlevi de bu türden bir gerginliğin simülasyonunu kurmacada yaşatarak çocuğun korkmayı normalleştirmesi; yani çocuğun duygusal olarak kendini geliştirmesidir. Güzel söyleme, "hüsn-ü talil” ya da "euphemism" diye adlandırabileceğimiz bir teknikle çevirmen kaynak metindeki bu işlevi azaltııştır.

Kaynak metinde kâ̆̆gt bebekler çimlerde yürür ancak çimler kağıt bebekler için ağaç kadar büyüktür, zaten yazar tarafından bu ortam "çim ormanı" şeklinde bir eğretilemeyle betimlenmiştir. Çevirmen ise bu karşılığı fazla yabancılaştırılmış bir seçenek olarak ve belki de kavramsal olarak fazla yüklü bulduğu için sadeleştirir: "Otların arasında yürüdüler, çiçekleri kokladılar. Bir uğur böceğiyle sohbet ettiler. Sonra da çimenlerin üstüne uzandılar.” Burada yüklemlerle oyun duraksatılmakta, hayal gücünü zenginleştirici sesler elenmektedir. Metnin yazınsallığı indirgenerek biçem basitleştirilmektedir.

Son tehlike, kaynak metne göre kâğıt bebekleri makasla paramparça eden bir çocuktur. Ardından da çocuk "işte şimdi sonsuza dek bittiniz" gibi bir şey söyler. Bu durum çevirmene göre bir çocuk tarafından duygusal olarak kabul edilmesi çok zor gelmiş olmalı ki çocuğun yaramaz olduğu bilgisi önceden verilmiş, yaptığı yaramazlık yine güzel söyleme tekniğiyle yumuşatılmıştır: "Ancak kısa süre sonra yaramaz bir çocuk geldi. / Elinde bir makas vardı. 'Sizlerden konfeti yapacağım!' dedi. / Sonra da 
dediğini yaptı. / Bütün bebekleri minik parçalara böldü ve rüzgâra savurdu. / 'Çok güzel konfeti oldunuz!' dedi.”

Kâğıt bebeklerin giderek büyüyen çatışmalarından sonuncusu olan bu durum, anlatının da doruk noktasıdır. Kâğıt bebekler yine şarkı söyleyip dans ederek kızın hayal dünyasında/ belleğinde birleşiverirler. Oysa çevirmen kâğıt bebeklerin üzülmediğine vurgu yapma ihtiyacı hissetmiş, yine okurda oluşacak duyguyu sabitlemeye çalışmıştır: "Kâğıt bebekler üzülmüş gibi görünmüyorlardı. / Tekrar şarkı söylemeye başladılar."

Çevirmen kızın belleğindeki anıların betimlemesinde de kaynak metinde bulunmayan kimi sıfatlar kullanmıştır. Burada kâğıt bebeklerin bulduğu şeyler harikadır, her gün harikadır, böylece eğlenceli yıllar geçirirler. Kaynak metinde bulunmayan bu sıfatlar aslında bazı üzücü şeylerin de var olabileceği ima edilen belleği tamamen olumlu bir yer olarak göstermektedir. Çevirmenin başvurduğu güzel söyleme tekniğiyle travmatik durumun yumuşatılması, kaynak metindeki duygusal gelişimi destekleme ve hayal gücünü, yaratıcılığı geliştirme işlevlerini indirgemiştir.

\section{Sonuç}

Sonuç olarak kaynak metnin odağında görünen yaratıcılık güdümleyici, duygusal gelişimi destekleyici, sosyalleştirici, eğlendirici işlevler ikincil plana atılarak eğitici-öğretici-bilgilendirici işlev odağa yerleştirilmiştir. Korumacı bir yaklaşımla metnin biçemsel zenginliği indirgenmiş, erek kültüre ait değerlerin ön planda tutulmasıyla metne çevirmen tarafından öz-sansür uygulanmıştır. Öte yandan eklemelerle metin uzamış, böylece çocukların dikkat süreleri göz önünde bulundurulduğunda okunması daha zor bir metin ortaya çıkmıştır. Ses benzeşmelerinin aktarılmamasıyla metin sesli okunmak için daha az ilgi çekici hale gelmiştir. Okuma sürecinde çocuğun duygu durumunda büyük değişimler yaşatmama doğrultusunda tedbirli davranılmış, böylece anlatıdaki heyecan unsurları azaltılmıştır. Sonuç olarak eğlendirici işlev açıkça indirgenmiştir.

Yukarıda sözü edilen çeviri çocuk yazınına ilişkin yaklaşımlar ışığında düşünüldüğünde, Sevgi Atlıhan'ın çeviri kararları Gillian Lathey’in altını çizdiği didaktik çeviri yaklaşımıyla örtüşmektedir. Erek metnin ana karakteri aracılığıyla okurlara (ya da dinleyicilere) sorumluluk duygusu aşılanmaya, kâğıt bebek yapımı konusunda bilgi aktarılmaya, akıllı, cesur, korkusuz olunması konusunda doğrudan yönlendirme yapılmaya çalışılmaktadır. Bu uğurda metnin işlev odakları kaydırılmıştır. Çevirmenin pedagojik olarak doğru bulmadığı ya da erek normlarda kabul görmeyeceğini düşünerek aktarmadığı unsurlar, erek odaklı bir çeviri anlayışından yana olduğunu gösterir. Öte yandan bu derece müdahaleci bir çeviri sürecini göze alması, görünür bir çevirmen olma çabası şeklinde de yorumlanabilir.

Sevgi Atlıhan’ın bu çevirisindeki işlevi kaydırma kararı, ilgili çeviriyi "kötü” ya da "yanlış" bir çeviri yapmaz. İşlevsel yaklaşıma göre çevirmen, bilincinde ve sorumluluğunda olduğu sürece çeviri kararlarıyla kaynak metnin işlevini dönüştürebilen uzman kişidir. Bu yaklaşımın çeviri eleştirisi yöntemini geliştirmiş olan Hans J. Vermeer'e göre çeviri eleştirisinde işlevsel eşdeğerlik arama çabası boş bir çabadır. Banu Telioğlu’nun Vermeer’in bir bildirisinden durumu tespiti şöyledir:

“Kuramcı 'Çevirinin Doğası' (2004) başlıklı bildiri metninde kültür kuramcılarının getirdiği en büyük yeniliklerden biri sayılan 'işlevsel eşdeğerlik' kavramını eleştirerek çeviride işlevler arasında bir özdeşliğin, bir eşdeğerliğin ya da en azından yakın bir benzerliğin yakalanması gerektiğini ortaya koyan çeviri modelinin yanlış olduğunu ileri sürer.” (Tellioğlu 2018, 200) 
Ancak çevirmenin, yukarıda da sözü edildiği gibi, kaynak metnin işlev odaklarındaki kaymanın bilincinde ve sorumluluğunda olması gerekmektedir. Atlıhan bu çevirisini eğitici, öğretici, bilgilendirici işlevde odaklarken sıkıcı, sı ̆̆, korumacı çocuk yetiştirme yaklaşımları doğrultusunda bir erek metin hedeflemiş olabilir mi? Yoksa içgüdüsel olarak ve erek kültürdeki normların kendi çeviri bilincinde yarattığı bakışla mı hareket etmiştir? Çeviri süreci öncesinde hedef kitlesini kimler olarak belirlemiştir? Bu belirlemede yayınevinin bir müdahalesi olmuş mudur? Çocuk yazını çevirisinin eleştirisi, en azından yerel bağlamda bu tür soruların farklı metinlere, çevirmenlere ve yayınevlerine sorulmasını beklemektedir.

Çocuk yazını çevirisinin zorlukları, yetişkin yazınının çevirisinden az değildir. Çeviri öncesi süreçte karar verilmesi gereken birçok değişken vardır. Bu yazıya konu olmuş örneklemde bu değişkenlerden eğiticiöğretici-bilgilendirici bir erek metin ortaya koyma çabası en bağlayıcı unsur olmuştur. Bu çabanın sonucu da yukarıda saptanmıştır. Çevirmen, erek kültürdeki çocuğa kitap okuma ediminin eğlendirici, yaratıcılık aşılayıcı, duygusal gelişimi destekleyici, yazınsal farkındalıkları arttırıcı işlevlerinin ebeveynler için çok geçerli olmayacağını varsaymış olabilir. Erek kültürdeki korumacı çocuk yetiştirme yaklaşımının yaygınlığını düşünerek metinde üstü kapalı ya da eksik bulduğu kimi içeriği açılamış ve eklemiş, çok tehlikeli bulduklarını yumuşatmış ya da çıarmıştır.

Bütün bu kararlar, okul öncesi resimli çocuk kitaplarının çevirisinde hedef kitleyi çocuk olarak tanıyan bir pedagojik çeviri² yaklaşımının ortaya atılıp atılamayacağı sorusunu gündeme getirebilir. Kaynak metnin 'çocuklar anlasın diye' basitleştirilirken yazınsal karmaşıklı̆̆ının feda edilmesi ya da 'çocuğa zarar vermesin' endişesiyle yumuşatılırken anlatısal derinliğinin feda edilmesi pedagojik bir bakışla uzman çevirmenler tarafından dengelenebilir unsurlardır. Bildirinin başında sözü geçtiği gibi bu alan, başından sonuna çocuğu hedef alan ancak birçok uygulamasında çocuktan uzaklaşıp yetişkin kararlarına boğulan bir alandır. Pedagojideki güncel yaklaşımlarla, yerele özgü durumları da göz önünde bulundurarak ve erek-kaynak odağından çok işlev odağı üzerinde karşılıklı metin incelemeleri yaparak çeviri çocuk yazını eleştirisini ve çocuk yazını çevirilerini daha olumlu bir noktaya taşımak olası ve yerinde bir çabadır.

\section{Kaynakça}

Donaldson, J. (2012). The Paper Dolls, London: Macmillan Children's Books.

Donaldson, J. (2016). Kâğıt Bebekler. Çev.: Sevgi Atlıhan. İstanbul: Türkiye İş Bankası Kültür Yayınları.

Lathey, G. (2006). “The Translator Revealed: Didacticism, Cultural Mediation And Visions Of The Child Reader İn Translator's Prefaces”. In: Van Collhe, J.; Verschueren, W. P. Children's Literature İn Translation: Challenges And Strategies. Manchester: St. Jerome, S.1-18.

Oittinen, R. (2000) Translating For Children. New York: Garland Publishing, Inc.

Shavit, Z. (1991). "Çocuk Yazın Çevirisinin Yazınsal Çoğuldizgedeki Konumu Açısından Belirlenmesi”, Çeviren: Pınar Besen. Metis Çeviri Bahar, S. 19-24

Shavit, Z. (2006). Translation Of Children's Literature. In: Lathey, G. The Translation Of Children's Literature: A Reader. Clevedon: Multilingual Matters Ltd, S. 25-40.

Stolze, R. (2003). “Translation For Children - World View Or Pedagogics?", Meta Translation For Children. Ed. Riitta Oittinen. Montreal: Presses Universitaires, S. 208-211.

\footnotetext{
$2 \quad$ Bu kavram literatürde tarandığında ortaöğretimde bir yabancı dil öğretim yöntemi olarak karşımıza çıkmaktadır. Bu yöntemde öğrenciye ilgili yabancı dilden ana diline çeviri yapması istenir. Ancak terimin yukarıdaki makalede kullanılan içeriği bununla uyuşmamaktadır. İlgili bağlamda bu kavram, çocuk yazının çevirisindeki yaklaşımların çağdaş pedagoji bulgularıly koşut olmasından söz etmektedir.
} 
Tellioğlu, B. (2018). Şiir Çevirisi Eleştirisinde Çevrilebilirlik/Çevrilemezlik İkiliğini Aşmak. Rumelide Dil Ve Edebiyat Araştırmaları Dergisi, (11), 192-213. Do1: 10.2900o/Rumelide.417493.

Van Coillie, J.; Verschueren, W. P. (2006). Children's Literature İn Translation: Challenges And Strategies. Manchester: St. Jerome.

Vermeer, H.J. (1989). Skopos And Commission In Translational Action, Lawrence Venuti (2000) The Translation Studies Reader Routledge, London. 